\title{
MULTICRITERIA EVALUATION OF THE USE OF ICT IN RURAL AREAS IN THE EUROPEAN UNION COUNTRIES IN 2018
}

\author{
Aneta Becker, DSc ${ }^{1 *}$; Jarosław Becker, DSc ${ }^{2 * *}$ \\ ${ }^{1}$ Faculty of Economics, West Pomeranian University of Technology \\ 2 Faculty of Technology, Jacob of Paradyz University in Gorzów Wielkopolski \\ ${ }^{*}$ https://orcid.org/0000-0001-6498-078X \\ ${ }^{*}$ https://orcid.org/0000-0001-7178-8569
}

\begin{abstract}
Information and communication technologies (ICT) are becoming more accessible and more widely used in different areas of socio-economic activity and in various territories, including rural areas. There is a noticeable increase in the interest of rural residents in modern technologies, especially those supporting communication. At the same time, it should be noted that despite the small level of ICT skills and competences, rural areas have great potential that can be expressed in: human resources, the natural environment biodiversity, and raw materials. Therefore, rural areas in Europe should be similar in terms of the use of ICT and should not differ from the level observed in urban areas.

The article presents the use of the AHP method (Analytic Hierarchy Process) for multicriteria decision analysis of the use of ICT by natural persons living in rural areas of the European Union (EU), in 2018. The empirical material used in the research came from the resources of the European Statistical Office (Eurostat). The result of the survey is the ranking of $27 \mathrm{EU}$ countries (Great Britain was omitted). The obtained results showed large disproportions in the use of ICT in rural areas between the countries of the European Union. In the extreme case, between Denmark being the leader of the ranking and Bulgaria, which was in the 27th place, this differences amounted to $70.7 \%$.
\end{abstract}

Key words: level of ICT use, natural person, rural areas, European Union, MCDA, AHP JEL codes: C38, O35

\section{INTRODUCTION}

At present, the transformation of the global economy towards the digital economy can be seen, and information and communication technologies (ICT) have become its foundation. These changes influenced the functioning of societies and all branches of the economy, thus opening up large opportunities in terms of: innovation, stimulating economic growth and creating jobs. In May 2015, the European Commission adopted the Digital Single Market Strategy for Europe (European Commission, 2015) as one of the top ten political priorities. According to the creators of the strategy, the uniform digital market is a space in which the free movement of goods, persons, services and capital is ensured and a high level of protection of

${ }^{1}$ Corresponding author: Janickiego 31, 71-270 Szczecin, Poland, abecker@zut.edu.pl, +4891 4496861

${ }^{2}$ Corresponding author: Chopina 52, 66-400 Gorzów Wielkopolski, Poland, jbecker@ajp.edu.pl, +4895 7279536 
consumers and personal data, and citizens and businesses can get access to or provide online services without hindrance and fair competition rules, regardless of citizenship or place of residence.

The elaboration of the new rural policy presented under the OECD's Rural Policy 3.0 (OECD, 2018) discusses six major trends that analysts believe will be observed in these areas in the $21^{\text {st }}$ century. A technological breakthrough has been mentioned among a number of global changes. It is expected that many new communication technologies and digital skills, including automation and artificial intelligence, cloud processing and use of the Internet, as well as nanotechnologies, will lead to significant savings, expansion of production capabilities, overcoming distance barriers and changing the ways of access to goods and services. The use of such solutions as 3D printing or the use of drones is not excluded.

The aim of the article is to classify EU countries in terms of the use of ICT by natural persons living in rural areas in 2018. The studies used the method of multicriteria AHP decision support. The empirical material used in the research came from the Eurostat data (Statistical Office of the European Union).

\section{USE OF ICT IN RURAL AREAS (LITERATURE REVIEW)}

Among the interesting topics discussed in recently published papers on the use of ICT in rural areas in the EU there is the digital literacy of older rural community representatives using a social network with linear navigation (Castilla et al., 2018). Cavicchi et al. presented a case of an international student competition which aim was to actively promote one of the Italian regions (Fermo, Marche region) via social media (Cavicchi et al., 2018). The issue related to e-administration and research on its impact on rural development is included in the article (Rana, 2018). Changes in the last dozen or so years in the availability and use of broadband connections in rural areas in the UK have been highlighted by the authors of the article (Price, Shutt and Sellick, 2018). The paper contains proposals for business support that can contribute to increasing access to new technologies in rural areas. Nagy et al. presented their thoughts on smart cities and villages. They characterized barriers and limitations that occur in rural areas and focused on the assessment of human resources as one of the most important preconditions to become intelligent (Nagy, Káposzta and Varga-Naget, 2018).

Szeles presented a new perspective on the phenomenon of digital exclusion in the European Union (Szeles, 2018). The author listed the following as the factors that could alleviate the regional digital divide: stimulating regional economic growth, increasing the achievements of higher education as well as spending on research and development and discouraging early educational leave. The next publication in this area focuses on the potential benefits and challenges facing ICT in the rural community (Treinen, Van der Elstraeten and Pedrick, 2018).

Nosecka and Zaremba characterized the information society in rural areas in Poland against the background of other EU member states (Nosecka and Zaremba, 2018). They pointed out that the society, regardless of the place of residence, relies primarily on knowledge, and is characterized by: a desire to learn, increase work efficiency and introduce modern ICT and innovation. The authors of the article (Costea, Arionesei and Hapenciuc, 2018) focused on determining the current state of ICT use by the population of EU countries living in the central and eastern parts of Europe. The authors carried out a detailed analysis between Romania and Bulgaria. The factors that contributed to the poor use of ICT in the analysed countries include insufficient development of ICT infrastructure in rural areas, caused by low: economic development, population purchasing power and educational level in the use of ICT. Similar analyses and forecasts of the phenomenon of digital exclusion in the countries of Central Europe are presented in the works (Becker et al., 2018; Ziemba and Becker, 2019) and in Poland (Becker and Becker, 2018).

\section{THE AHP METHOD}

Saaty, the author of the AHP method, began work on the construction of the algorithm in the 1970s (Saaty, 1977, 1980, 2008; Saaty and Tran, 2007). In many publications, this method is presented as an effective tool for solving complex decision problems that can 
be presented in the form of a multi-level hierarchical structure. It is useful in situations where the criteria are qualitative, and the assessments are subjective and result from the knowledge and experience of the analyst.

The literature discusses many applications of the AHP method in various areas of socio-economic life, e.g. multicriteria rating of: real estate offers (Becker and Becker, 2017), techno-entrepreneurship projects (Unutmaz Durmuţođlu, 2018), risk in supply chain (Butdee and Phuangsalee, 2019). Over 400 examples of decision problems, both at governmental level and of private organizations, have been published in the book by Saaty and Forman (1996). Among the works published in the recent period, which address the problems of rural areas and present solutions using AHP, the article by Kumar and Kansara (2018) deserves attention. The authors set a goal of finding possible barriers to IT applications in the sugar industry supply chain system in India. Another offer was created by the article by Jafari, Jafari and Shahbazi (2018), which focuses on the selection of the location of a rural waste landfill and the complex issues of managing it. The paper by Ma et al. (2018) contains an assessment of the impact of the policy protecting land with the urban-rural construction policy on the future rural landscape. Interesting results are presented in the article by Zhang, Yang and Zhao (2018). The authors used AHP and FCE to assess the performance of various rural heating systems and determine the most appropriate type of system.

Using the AHP procedure, we begin by defining the purpose and by defining a coherent family of criteria relevant to the decision problem. Then, comparison matrices for criteria and decision variants are constructed and appropriate calculations are made to determine priorities in the form of scale vectors and their aggregation. A detailed description of the AHP procedure is presented, among others, in the works of Saaty $(1980,2008)$ and Trzaskalik (2006).

The aggregation of assessment in the AHP method takes place according to the additive utility function, synthesizing the weight fractions or criteria and the values of the degree of fulfilment for the fractional objective function by each criteria. Assessment of the degree of the fulfilment of these criteria for the considered decision variants are obtained by the Saaty method of pair comparisons, used to determine the normalized eigenvector (Saaty, 2005, 2008).

\section{USE OF ICT BY INDIVIDUALS IN RURAL AREAS (EMPIRICAL MATERIAL)}

The empirical material containing information on the use of ICT by natural persons in the European Union (EU), in 2018 came from Eurostat data resources (Eurostat, 2019a). Participation in the direct interview was voluntary, and participants were 16-74-year-olds living in rural areas of the EU-28 member states. The published data is collected annually by national statistical offices and is based on the annual model questionnaires of Eurostat on the use of ICT by natural persons. A large part of the collected data is used to monitor the digital economy and society; project for 2016-2021 (Eurostat, 2019b).

Analysing the collected empirical material, we can conclude that digital technologies play an important role in the everyday life of most Europeans. In 2018, almost $70 \%$ of people living in rural areas of the EU used the Internet every day. The highest percentage of network users was recorded in Denmark (80\%) and the Netherlands (88\%), while the lowest in Romania and Bulgaria (42\%). In Poland, this percentage was 54\%. The most popular types of broadband access to the Internet was a digital subscriber line (DSL), almost universally available across the EU, or a less widespread cable (optical fibre). The dominant Internet connection, at the level of $85 \%$, was the broadband connection. The inhabitants of the rural areas of the Netherlands (98\%) most often used this type of connection. In turn, the lowest percentage of broadband access was found in Bulgaria (60\%) and Greece (63\%). In Poland, this solution was at the level of $82 \%$.

Below the average, the Internet was used to communicate with public authorities. In 2018, in the EU, it was at the level of $47 \%$, in Poland $-25 \%$. However, in Denmark, this percentage was very high and amounted to $90 \%$. While the lowest percentage was recorded in Romania - 6\%. Among reasons that limited contact with the administration via the Internet, there was a lack of skills and knowledge. At the same time, only $4 \%$ of the surveyed residents of rural areas 
of the EU and 5\% of inhabitants of Poland were characterized by this feature. There were also countries where no such obstacles were noticed, for example, in Finland, France and Portugal.

e-Commerce is an important area of ICT interest in the EU's rural areas. More than half (56\%) of the surveyed residents of these areas made online purchases - in Poland $46 \%$. The highest percentage of clients was recorded in Denmark (82\%) and the Netherlands (78\%), while the lowest in Romania (14\%) and Bulgaria $(13 \%)$. The smallest percentage of people made online purchases: from sellers of unknown country of origin and computer hardware. The purchases most willingly bought were: from domestic sellers, clothes and sports articles, household goods, films, music or books, magazines, e-learning materials or computer software, and accommodation reservations were made (Eurostat, 2018).

\section{RANKING OF EU COUNTRIES IN TERMS OF THE LEVEL OF ICT USE IN RURAL AREAS}

The aim of the study was to assess the level of ICT use by natural persons living in rural areas in $27 \mathrm{EU}$ countries in 2018. Due to the lack of data, Great Britain was omitted. The research used a set of four main criteria, which included the:

- $\mathrm{C}_{1}$ - frequency of Internet access: once a week, including every day $\left(w_{1}=0.210\right)$;

- $\mathrm{C}_{2}$ - household Internet connection type: broadband $\left(w_{2}=0.098\right)$;

- $\mathrm{C}_{3}$ - e-government activities of individuals via websites $\left(w_{3}=0.346\right)$ :

- $\mathrm{C}_{3.1}$ - Internet use: obtaining information from public authorities web sites $\left(w_{3.1}=0.196\right)$,

- $\mathrm{C}_{3.2}$ - Internet use: downloading official forms, last 12 months $\left(w_{3.2}=0.311\right)$,

- $\mathrm{C}_{3.3}$ - Internet use: submitting completed forms, last 12 months $\left(w_{3.3}=0.493\right)$,

- $\mathrm{C}_{4}-$ Internet purchases by individuals $\left(w_{4}=\right.$ $=0.346)$;

- $\mathrm{C}_{4.1}$ - last online purchase: in the 12 months $\left(w_{4.2}=0.5\right)$,

- $\mathrm{C}_{4.2}$ - online purchases of products and services $\left(w_{4.2}=0.5\right)$, this criterion consists of purchases of: $\mathrm{C}_{4.2 .1}-$ food/groceries, $\mathrm{C}_{4.2 .2}-$ household goods,
$\mathrm{C}_{4.2 .3}$ - clothes, sports goods, $\mathrm{C}_{4.2 .4}-$ films $/ \mathrm{mu}$ sic or books/magazines/e-learning material or computer software, $\mathrm{C}_{4.2 .5}$ - computer hardware, $\mathrm{C}_{4.2 .6}$ - electronic equipment, $\mathrm{C}_{4.2 .7}$ - tickets for events, $\mathrm{C}_{4.2 .8}$ - travel and holiday accommodation, $\mathrm{C}_{4.2 .9}$ - telecom services (all of the weights are equal: $\left.w_{4.2 .1}, w_{4.2 .2}, \ldots, w_{4.2 .9}=1 / 9\right)$.

All criteria were measurable and expressed in percentages. These values on each undivided criterion $\left(\mathrm{C}_{1}, \mathrm{C}_{2}, \mathrm{C}_{3.1}, \mathrm{C}_{3.2}, \mathrm{C}_{3.3}, \mathrm{C}_{4.1}\right.$ and $\left.\mathrm{C}_{4.2 .1}, \ldots, \mathrm{C}_{4.2 .9}\right)$ were transformed into the form of scale vectors, where element totals (27 countries) equalled one. The weight values for individual criteria are shown in brackets. Weight vectors were determined using the Saaty method, comparing pairs of criteria at each level of the hierarchical structure. The principle was applied, according to which higher priority was given to criteria reflecting the use of ICT with a higher degree of advancement. The set of main criteria most strongly preferred $\mathrm{C}_{3}-$ e-government activities $\left(w_{3}=\right.$ $=34.6 \%)$ and $\mathrm{C}_{4}-$ Internet purchases $\left(w_{3}=34.6 \%\right)$. The weights of sub-criteria for $\mathrm{C}_{3}$ were also differentiated, placing $\mathrm{C}_{3.3}$ in the first place - submitting completed forms $\left(w_{3.3}=49.3 \%\right), \mathrm{C}_{3.2}$ in the second place - downloading official forms $\left(w_{3.2}=31.1 \%\right)$ and $\mathrm{C}_{3.1}$ in the last place - obtaining information from public authorities web sites $\left(w_{3.1}=0.196\right)$.

The AHP computational procedure was performed twice and two rankings were obtained (Fig. 1). The first ranking was made for comparative purposes, without taking into account the designated priorities (all criteria are equally preferred), the second one with their inclusion (the criteria for using advanced internet services are more preferred). The assessments of the countries that created the second ranking are additionally presented in Figure 2. The results of both analyses indicated stable (independent of changes in preferences) positions in 14 out of 27 surveyed countries. The highest level of ICT use in rural areas in 2018 was obtained by Denmark. The Netherlands came second with $93.2 \%$ and with Sweden following it $(92.9 \%)$. The next two places were taken by: Finland $(87.6 \%)$ and Estonia $(86.6 \%)$. The last, $27^{\text {th }}$ place, in the ranking was obtained by Bulgaria, in which the level of using advanced Internet services in rural areas constituted only $29.3 \%$ compared 
Proceedings of the 2019 International Scientific Conference 'Economic Sciences for Agribusiness and Rural Economy' No 3, Warsaw, 5-7 June 2019, pp. 38-45

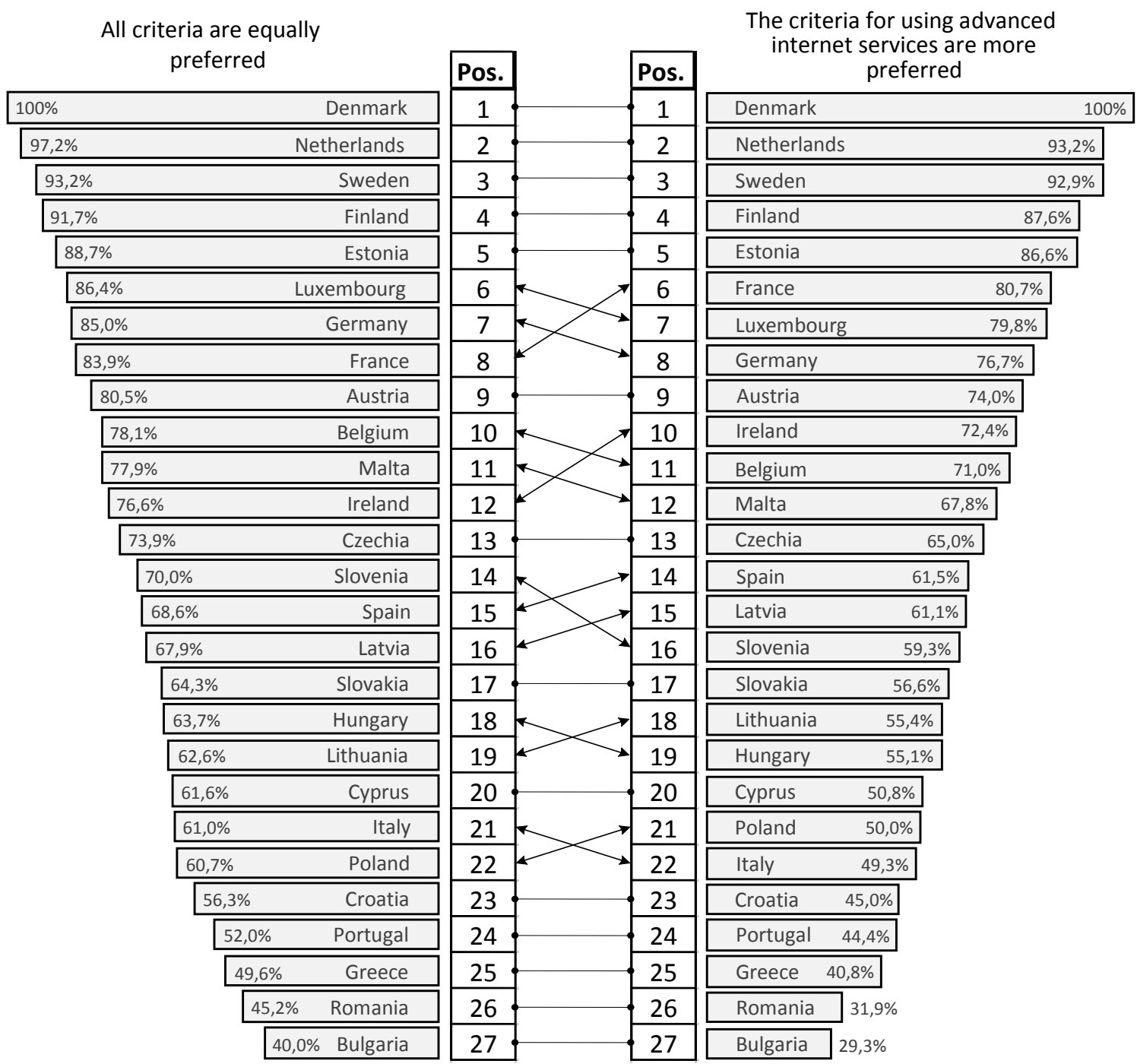

Figure 1. The ranking of EU countries in terms of the level of ICT use by individuals in rural areas in 2018

Source: own study based on Eurostat data (Eurostat, 2019a).

to Denmark. Bulgaria was ranked just before Bulgaria (31.9\%). Slightly better evaluations were obtained by: Greece (40.8\%), Portugal (44.4\%), Croatia (45\%), Italy (49.3\%) and Poland (50\%).

Comparison of the positions of the countries in both rankings distinguished France and Ireland, which initially, in the ranking with aligned priorities for the criteria, took the $8^{\text {th }}$ and $12^{\text {th }}$ place, respectively, and after considering the higher rank for e-government activities and Internet purchases they advanced two positions. The reverse phenomenon was observed in the case of Slovenia, which dropped by two positions in the ranking highlighting the level of use of advanced Internet services.

\section{SUMMARY}

Considering the use of ICT by natural persons in rural areas in 2018, there are significant discrepancies between member states. Northern and western EU countries have higher ICT usage than countries located in the south or east (Eurostat, 2018). Based 
on the results of the study, it can be concluded that the rural areas with the lowest use of ICT and at the same time with a high degree of risk of physical exclusion of natural persons were: Bulgaria, Romania, Greece, Portugal, Croatia, Italy and Poland (Fig. 2, the lightest shade). The evaluations of these countries did not exceed half $(50 \%)$ of the rating obtained by the leader, i.e. Denmark. Together with Denmark, the Netherlands, Sweden, Finland, Estonia, followed by France, Luxembourg and Germany (Fig. 2, the darkest shade) qualified for the group of countries least exposed to the phenomenon of digital exclusion in rural areas. These countries scored more than $75 \%$ of the best result.

The reasons that led to the disproportion presented include: low income, lack of infrastructure in rural areas, which limited access to digital technologies and their availability, insufficient education and computer skills, as well as cultural factors. In order to reduce regional disparities, one should strive to raise social capital, activate the unemployed, pensioners and promote the use of ICT in professional and private life.

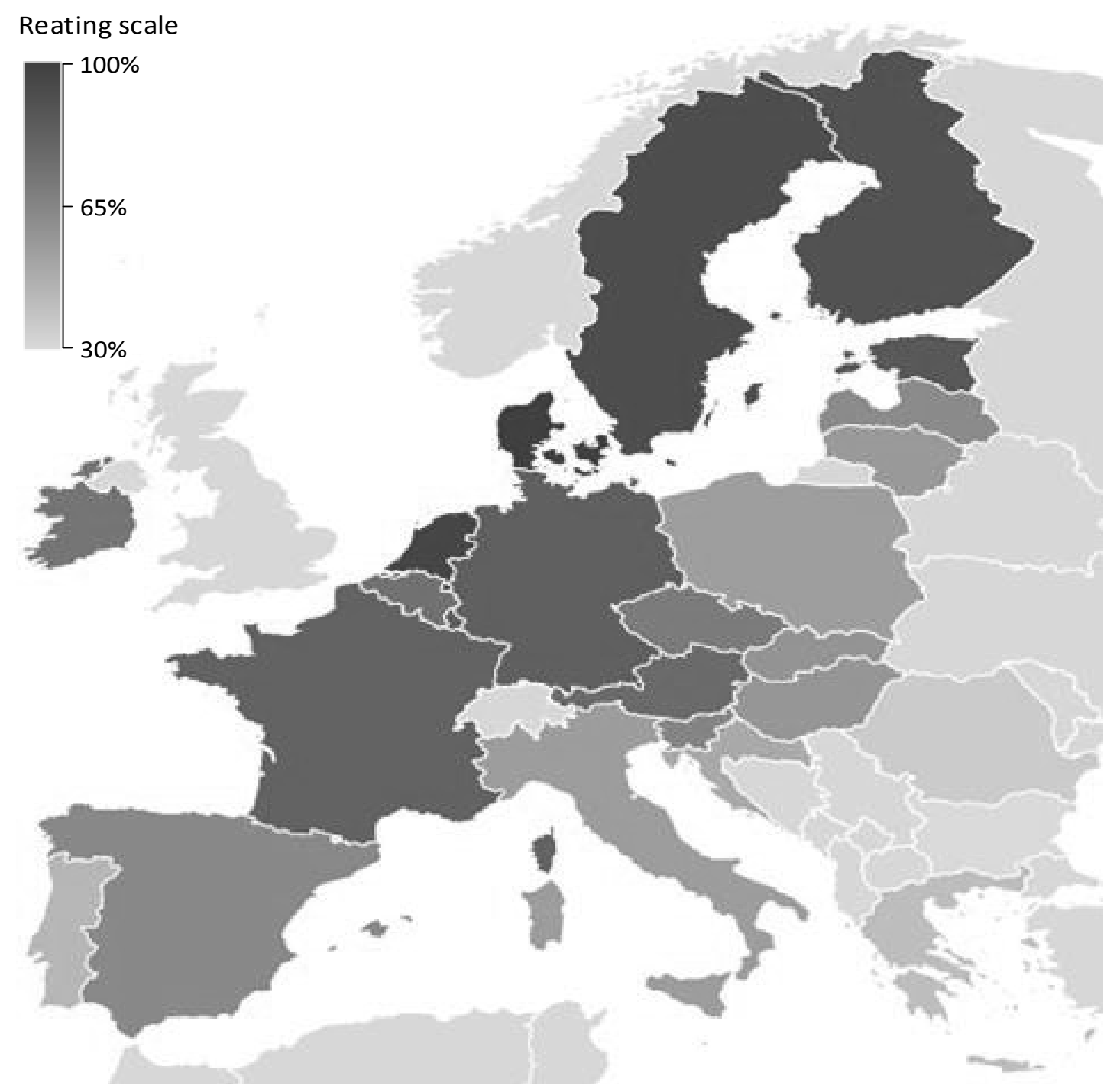

Figure 2. The levels of ICT use by natural persons in rural areas of EU countries in 2018

Source: own study based on Eurostat data (Eurostat, 2019a). 


\section{REFERENCES}

1. Becker, A., Becker, J. (2017). A Selection of Offers on the Szczecin Residential Market with the AHP Method. Folia Oeconomica Stetinensia, 17 (1), pp. 68-79, https://doi.org/10.1515/foli-2017-0006

2. Becker, A., Becker, J. (2018). Regional differentiation of Poland in terms of the degree of digital exclusion of households in 2017. In: Proceedings of the 2018 International Scientific Conference 'Economic Sciences for Agribusiness and Rural Economy', pp. 306-312, https://doi.org/10.22630/ESARE.2018.2.41

3. Becker, J., Becker, A., Sulikowski, P., Zdziebko, T. (2018). ANP-based analysis of ICT usage in Central European enterprises. In: Procedia Computer Science, Knowledge-Based and Intelligent Information \& Engineering Systems: Proceedings of the 22nd International Conference, KES-2018, Belgrade, 126, pp. 2173-2183, https://doi.org/10.1016/j.procs.2018.07.231

4. Butdee, S., Phuangsalee, P. (2019). Uncertain risk assessment modelling for bus body manufacturing supply chain using AHP and fuzzy AHP. Procedia Manufacturing, 30, pp. 663-670. https://doi.org/10.1016/ j.promfg.2019.02.094

5. Castilla, D., Botella, C., Miralles, I., Bretón-López, J., Dragomir-Davis, A.M., Zaragoza, I., Garcia-Palacios, A. (2018). Teaching digital literacy skills to the elderly using a social network with linear navigation: A case study in a rural area, International Journal of Human-Computer Studies, 118, pp. 24-37, https://doi. org/10.1016/j.jhcs.2018.05.009

6. Cavicchi, A., Frontoni, E., Pierdicca, R., Rinaldi, C., Bertella, G., Santini, C. (2018). Participatory location-based learning and ICT as tools to increase international reputation of a wellbeing destination in rural areas: a case study. In: I. Azara et al. (eds.) Tourism, Health, Wellbeing and Protected Areas. CABI, Wallingford, pp. 82-94, https://doi.org/10.1079/9781786391315.0082

7. Costea, M., Arionesei, G., Hapenciuc, C.V. (2018). The adoption and use of new information and communication technologies at the level of CEE-EU countries. In: CBU International Conference Proceedings, 6, p. 69, https://doi.org/10.12955/cbup.v6.1135

8. European Commission (2015). Communication from the Commission to the European Parliament, the Council, the European Economic and Social Committee and the Committee of the Regions. A Digital Single Market Strategy for Europe. COM(2015) 192 final of 06.05.2015.
9. Eurostat (2018). Statistics on rural areas in the EU - Statistics Explained. Retrieved from: https://ec.europa.eu/ eurostat/statistics-explained/index.php/Statistics_on_rural_areas_in_the_EU\#Education [Accessed 06.04.2019].

10. Eurostat (2019a). Database - Eurostat. Retrieved from: https://ec.europa.eu/eurostat/ web/degree-of-urbanisation/data/database [Accessed 06.04.2019].

11. Eurostat (2019b). ICT usage in households and by individuals (isoc_i). Reference Metadata in Euro SDMX Metadata Structure (ESMS). Retrieved from: https:// ec.europa.eu/eurostat/cache/metadata/en/isoc i esms. htm [Accessed 06.04.2019].

12. Jafari, M., Jafari, A., Shahbazi, R. (2018). Site selection of rural waste landfill using the AHP model and GIS software (Case study: the central part of Ejroud city). Journal of Health in the Field, 6 (2). Retrieved from: http://journals.sbmu.ac.ir/en-jhf/article/view/23242

13. Kumar, R., Kansara, S. (2018). Information technology barriers in Indian sugar supply chain: an AHP and fuzzy AHP approach. Benchmarking, 25, pp. 1978-1991, https://doi.org/10.1108/BIJ-01-2017-0004

14. Ma, B., Tian, G., Kong, L., Liu, X. (2018). How China's linked urban-rural construction land policy impacts rural landscape patterns: a simulation study in Tianjin, China. Landscape Ecology, 33, https://doi.org/10.1007/ s10980-018-0669-1

15. Nagy, H., Káposzta, J., Varga-Nagy, A. (2018). Is ICT smartness possible development way for Hungarian rural areas? In: Proceedings of 17th International Scientific Conference Engineering for Rural Development. Jelgava 23-25.05.2018, pp. 463-468, https://doi. org/10.22616/ERDev2018.17.N041

16. Nosecka, B., Zaremba, L. (2018). Information society in rural areas in Poland in comparison with other EU Member States (No. 276186). Paper presented at 166th EAAE Seminar, Galway 30-31.08.2018, https://doi. org/10.22004/ag.econ.276186

17. OECD (2018). RURAL 3.0. A framework for rural development. Retrieved from: https://www.oecd.org/cfe/ regional-policy/Rural-3.0-Policy-Note.pdf.

18. Price, L., Shutt, J., Sellick, J. (2018). Supporting rural Small and Medium-sized Enterprises to take up broadband-enabled technology: What works? Local Economy, 33, pp. 515-536, https://doi.org/10.1177/02690942 18791508

19. Rana, N. (2018). E-government \& e-governance: impact, issues and challenges in the development of rural areas. International Journal of Advance and Innovative Research, 5, pp. 59-65. 
20. Saaty, T.L. (1977). A scaling method for priorities in hierarchical structures. Journal of Mathematical Psychology, 15, pp. 234-281, https://doi.org/10.1016/00222496(77)90033-5

21. Saaty, T.L. (1980). The Analytic Hierarchy Process: Planning, Priority Setting, Resource Allocation. McGraw-Hill, New York.

22. Saaty, T.L. (2005). The Analytic Hierarchy and Analytic Network Processes for the Measurement of Intangible Criteria and for Decision-Making. In: S. Greco (ed.) Multiple Criteria Decision Analysis: State of the Art Surveys, International Series in Operations Research \& Management Science. Springer, New York, pp. 345 $-405$.

23. Saaty, T.L. (2008). Decision making with the analytic hierarchy process. International Journal of Services Sciences, 1 (1), pp. 83-98, https://doi.org/10.1504/ IJSSCI.2008.017590

24. Saaty, T.L. Forman, E.H. (1996). The Hierarchon: A Dictionary of Hierarchies. RWS Publications, Pittsburgh.

25. Saaty, T.L., Tran, L.T. (2007). On the invalidity of fuzzifying numerical judgments in the Analytic Hierarchy Process. Mathematical and Computer Model- ling, 46 (7-8), pp. 962-975, https://doi.org/10.1016/ j.mcm.2007.03.022

26. Szeles, M.R. (2018). New insights from a multilevel approach to the regional digital divide in the European Union. Telecommunications Policy, 42, pp. 452-463, https://doi.org/10.1016/j.telpol.2018.03.007

27. Treinen, S., Elstraeten, A., Van der, Pedrick, C. (2018). Gender and ICTs: mainstreaming gender in the use of information and communication technologies (ICTs) for agriculture and rural development. FAO.

28. Trzaskalik, T. (ed.) (2006). Multicriteria methods on the Polish financial market [Metody wielokryterialne na polskim rynku finansowym]. PWE, Warszawa.

29. Unutmaz Durmuțođlu, Z.D. (2018). Assessment of techno-entrepreneurship projects by using Analytical Hierarchy Process (AHP). Technology in Society, 54, pp. 41-46, https://doi.org/10.1016/j.techsoc.2018.02.001

30. Zhang, X., Yang, J., Zhao,X. (2018). Optimal study of the rural house space heating systems employing the AHP and FCE methods. Energy, 150, pp. 631-641, https://doi.org/10.1016/j.energy.2018.03.007

31. Ziemba, P., Becker, J. (2019). Analysis of the Digital Divide Using Fuzzy Forecasting. Symmetry, 11 (2), 166, https://doi.org/10.3390/sym11020166 